\title{
Prevalence of odontogenic pain and associated factors in children treated at a pediatric dental emergency service
}

\author{
Camila Erlacher Muller ${ }^{\mathrm{a}}$, Manoelito Ferreira Silva Junior ${ }^{\mathrm{b}, \mathrm{c}}$, Elaine Cristina Vargas Dadalto ${ }^{\mathrm{a}}$, \\ Ana Paula Martins Gomes ${ }^{a}$, Lilian Citty Sarmento ${ }^{\mathrm{a}}$, Ana Maria Martins Gomes ${ }^{\mathrm{a}}$
}

\begin{abstract}
OBJECTIVE: To describe the prevalence and to analyze the factors associated with odontogenic pain among children at a pediatric dental emergency service.

METHODS: The retrospective cross-sectional study was performed using the clinical records of children (0 to 12 years old) attended from 2003 to 2010 at the Pediatric Dentistry Emergency Service of the Universidade Federal do Espírito Santo. The information was collected by a researcher, and a structured form was used to collect all data from patients' records. A bivariate analysis of the absolute and relative frequencies of odontogenic pain (spontaneous and induced) and associated factors (age, gender, diagnosis, treatment and referrals) was performed with the chi-square or Fisher tests $(p<0.05)$.

RESULTS: Of the 574 records examined, 308 (53.7\%) had reported odontogenic pain. The majority of the individuals were male $(51.0 \%)$ between 4 and 8 years of age $(40.9 \%)$. Odontogenic pain affected more frequently the deciduous tooth $(76.9 \%)$, with induced dental pain $(54.5 \%)$, diagnosed with dental caries (54.5\%), which was treated with extraction (21.4\%), and referred to another clinic $(59.7 \%)$. The type of odontogenic pain was not associated with gender, age group or affected tissue $(p>0.05)$, but there was a higher prevalence of spontaneous pain in children with caries in a deciduous tooth with pulpal involvement, who were treated with endodontic medication and endodontic treatment $(p<0.05)$. Among children with induced pain, there was a higher prevalence of trauma and decay in deciduous and permanent teeth without pulpal involvement, and they received temporary restoration and were referred to the trauma project $(p<0.05)$.

CONCLUSION: There was higher prevalence of odontogenic pain in children between 4-8 years of age, with deciduous dentition and dental caries. The type of odontogenic pain was associated with diagnosis, treatment and referral, but was not associated with gender and age.

Keywords: dental care for children; toothache; pediatric dentistry.
\end{abstract}

\section{Prevalência de dor odontogênica e fatores associados em crianças atendidas em pronto-socorro odontopediátrico}

\section{RESUMO}

OBJETIVO: Descrever a prevalência e analisar os fatores associados à dor odontogênica em crianças em um serviço de urgência odontopediátrica.

MÉTODOS: O estudo transversal retrospectivo foi realizado utilizando os registros clínicos de crianças ( 0 a 12 anos) atendidos de 2003 a 2010 no Serviço de Urgência em Odontopediatria da Universidade Federal do Espírito Santo. As informações foram coletadas, de forma estruturada, por um pesquisador a partir dos registros dos pacientes. Análise bivariada das frequências absolutas e relativas da dor odontogênica (espontânea e induzida) e os fatores associados (idade, sexo, diagnóstico, tratamento e referências) foi realizada com os testes de qui-quadrado ou Fisher $(p<0,05)$.

RESULTADOS: Dos 574 registros examinados, 308 (53,7\%) relataram dor odontogênica. A maioria dos indivíduos era do sexo masculino $(51,0 \%)$ entre 4 e 8 anos de idade $(40,9 \%)$. A dor odontogênica afetou mais freqüentemente dentes decíduos $(76,9 \%)$, de forma provocada $(54,5 \%)$, relacionada à presença de cárie dentária (54,5\%), que foi tratada com extração $(21,4 \%)$ e referida a outra clínica $(59,7 \%)$. O tipo de dor odontogênica não foi associado com gênero, grupo etário ou tecido afetado $(p>0,05)$, porém, houve maior prevalência de dor espontânea em dentes decíduos com cárie e envolvimento pulpar, que foram tratados com medicação endodôntica e tratamento endodôntico $(p<0,05)$. Entre as crianças com dor provocada, houve maior prevalência de trauma e cárie em dentes decíduos e permanentes sem envolvimento pulpar, que receberam restauração temporária e foram encaminhados para o projeto de trauma $(p<0,05)$.

CONCLUSÃO: houve maior prevalência de dor odontogênica em crianças entre 4-8 anos de idade, com dentição decídua e cárie dentária. O tipo de dor odontogênica foi associado à causa, tratamento e encaminhamento, todavia, não associado ao gênero e à idade.

Palavras-chave: cuidados dentários para crianças; dor de dente; odontoprdiatria.
${ }^{a}$ Federal University of Espírito Santo, Vitória, ES, Brazil

${ }^{b}$ Piracicaba Dental School, University of Campinas, Piracicaba, SP, Brazil

c State University of Ponta Grossa, Ponta Grossa PR, Brazil 


\section{INTRODUCTION}

Odontogenic pain still has a high prevalence in the world population and a high negative impact on children's quality of life [1-3]. Such impact interferes in their feeding, locomotion, social interactions [4], absenteeism from school $[5,6]$, sleep and recreational activities [7].

Odontogenic pain may be of pulp and/or periodontal origin. Pain from the dental pulp is classified as a somatic, deep and visceral pain, and it is difficult for the patient to locate the affected tooth. Periodontal pain is somatic, deep and musculoskeletal, being easily localized, especially when applying pressure. The common sources of odontogenic pain are the presence of dental caries reaching the dentin, with and without pulp involvement, periapical/periodontal abscess, and dental trauma [8].

Dental or odontogenic pain is one of the main reasons for the demand by pediatric patients for dental care, especially in emergency services [2,3,9-14]. The sensation of pain is personal and subjective, varying from individual to individual, since it is based in one's own history, sociocultural context, personality type, age, cognitive-developmental phase, and so forth [15].

Variation in pain experience is explained, among other factors, by differences in pain threshold and tolerance. Furthermore, it is related to sensitive (extension and localization of the tissue lesion), genetic (related to the nociceptive system and pain modulation), emotional (fear, anger, anxiety and depression), cultural (learning, previous experience, symbolic significance of pain), and social factors (possible economic, social, and affective secondary gain) $[16,17]$.

A significant number of children visits the dentist for the first time due to emergencies. However, little is known about the prevalence, etiology and treatment provided to children in emergency visits [12]. In spite of the growing interest on the subject, most studies are population-based in preschoolers $[3,4,14]$ or about the profile of children treated in dental emergency services $[9,11,12,18]$, without, however, verifying the factors associated with the reported conditions. Studies about dental pain in health services for children are rare [3].

In this regard, the objective of this study was to describe the prevalence and to analyze the factors associated with odontogenic pain among children at a pediatric dental emergency service.

\section{METHODOLOGY}

This research consists of a retrospective cross-sectional study, with data collected from the clinical records of children treated from 2003 to 2010 at the Pediatric Dentistry Emergency Service Project (PDESP) of the Universidade Federal do Espírito Santo (Ufes) in Vitória-ES, registered with SIEXBRASIL no. 20827. This project was performed by dental students who had already taken the class of pediatric dentistry, not influencing the demand for patients of other clinical classes of pediatric dentistry. The study began under approval of the Ethical Committee on Research from the Universidade Federal do Espírito Santo (no. 091/06) and the data was collected by only one researcher.

All children who sought the PDESP for care were duly identified and a clinical record was completed containing data from anamnesis, extra- and intra-oral clinical examination (soft and hard tissues), radiographic examination, diagnosis and procedures. All included records were properly filled by participants of an academic extension project on dentistry and an Informed Consent Form was signed by the child's legal guardian.

Data was collected from the clinical record containing information about the patient's personal profile, gender (male and female), place of residence, age (years), clinical and radiology exams performed for diagnosis, clinical procedures and referral to other services. Odontogenic pain was measured with data present on the patient's clinical record, namely questions asked to the child or parents (younger children) about the presence of odontogenic pain (no or yes/spontaneous or induced) and the specific site of the pain. No vitality tests were performed to measure odontogenic pain.

The deciduous teeth that presented dental caries with pulp involvement, received as treatment: extraction, endodontic treatment, or were referred to other services, according to the needs of the child. Endodontic treatment in deciduous teeth was performed according to a technique recommended by Guedes-Pinto [19]. Some permanent teeth with pulp involvement received endodontic dressing, systemic anti-inflammatory and antibiotic medication and were referred to other services. Dressing of the permanent teeth was performed with camphorated paramonoclophenol. The primary and permanent teeth that suffered trauma were treated according to the degree of the sequelae, in some cases, only clinical and radiographic follow-up and, in others, tooth extraction. In cases of prolonged retention of the deciduous tooth/early eruption of the permanent tooth, the deciduous tooth was extracted or a clinical follow-up was performed, for timely extraction. Periodontal changes occurred only in permanent teeth.

Data was tabulated using Microsoft Office Excel (2007) and the statistical software Statistical Package for Social Science 18 (SPSS). Descriptive analysis was done with relative and absolute frequencies and a bivariate analysis between the variables: presence of odontogenic pain (spontaneous and induced) and associated factors (age group, gender, diagnosis, treatment and referrals) was done with the chi-squared or Fischer tests at a significance level of $5 \%(\mathrm{p}<0.05)$.

\section{RESULTS}

From 2003 to 2010, 596 children were treated. After the analysis of their records, it was observed that 308 (53.7\%) reported odontogenic pain, and these were the records used for this study. 
Most of the patients of the pediatric dental emergency service were male $(51.0 \%)$ within an age group ranging from 4-8 years old (40.9\%). It was verified that 168 children (54.5\%) reported induced odontogenic pain and $140(45.5 \%)$ spontaneous pain. There was no association between the type of odontogenic pain and the gender or age group (Table 1).

Deciduous teeth were the most affected by odontogenic pain in 237 (76.95\%). There was no association between the type of pain and the affected tissue (Table 2).

The main diagnosis for the assisted children was dental caries, which occurred in 191 (60.2\%) children, followed by dental trauma in $70(22.0 \%)$. There was a greater prevalence of spontaneous pain (73.8\%) among children who had caries in a deciduous tooth with involvement of the dental pulp, and greater prevalence of induced pain in children with caries in a permanent $(83.3 \%)$ or deciduous $(71.4 \%)$ tooth without involvement of the dental pulp, and trauma in a permanent $(76.9 \%)$ or deciduous $(70.5 \%)$ tooth (Table 3).

The most performed procedures were the extraction of deciduous teeth $(21.4 \%)$, endodontic medication $(16.6 \%)$ and temporary restoration (10.7\%). In the cases of spontaneous pain, the types of procedures performed with a higher frequency were endodontic medication and endodontic treatment of deciduous teeth, while in cases of induced pain, the higher frequency treatment was temporary restoration (Table 4).

Not all children assisted in the PSO were offered dental treatment. Seventy-five children were referred to other services and 109 children who received first-aid care were referred to follow-up and further treatment in another clinic at the University. A total of 184 children (59.7\%) were referred to other services. The clinic of Pediatric Dentistry from Ufes was the one who received most children, 108 $(58.7 \%)$. There was no association between the type of pain and the referral of the child in most cases. Only the children who were referred to the dental trauma project were associated with induced odontogenic pain (Table 5).

Table 1. Frequency of odontogenic pain reported according to gender and age group of children who attended the PDESP. Bivariate analysis with chi-squared test. Vitória-ES, 2003-2010.

\begin{tabular}{|c|c|c|c|c|c|c|c|}
\hline \multirow{3}{*}{ Variables } & \multicolumn{6}{|c|}{ Type of pain } & \multirow{3}{*}{$p$-value } \\
\hline & \multicolumn{2}{|c|}{ Total } & \multicolumn{2}{|c|}{ Induced } & \multicolumn{2}{|c|}{ Spontaneous } & \\
\hline & $\mathrm{n}$ & $\%$ & $\mathrm{n}$ & $\%$ & $\mathrm{n}$ & $\%$ & \\
\hline \multicolumn{8}{|l|}{ Gender } \\
\hline Male & 157 & 51.0 & 82 & 48.8 & 75 & 53.6 & \multirow{3}{*}{0.410} \\
\hline Female & 151 & 49.0 & 86 & 51.2 & 65 & 46.4 & \\
\hline Total & 308 & 100.0 & 168 & 100.0 & 140 & 100.0 & \\
\hline \multicolumn{8}{|l|}{ Age (years) } \\
\hline $0-4$ & 87 & 28.3 & 54 & 32.2 & 33 & 23.6 & \multirow{4}{*}{0.350} \\
\hline $4-8$ & 126 & 40.9 & 58 & 34.5 & 68 & 48.6 & \\
\hline $8-12$ & 95 & 30.8 & 56 & 33.3 & 39 & 27.8 & \\
\hline Total & 308 & 100.0 & 168 & 100.0 & 140 & 100.0 & \\
\hline
\end{tabular}

Table 2. Frequency of the type of odontogenic pain reported according to the affected tooth and soft tissue of children who attended the PDESP. Bivariate analysis with chi-squared test. Vitória-ES, 2003-2010.

\begin{tabular}{|c|c|c|c|c|c|c|c|}
\hline \multirow{3}{*}{ Tissue } & \multicolumn{6}{|c|}{ Type of pain } & \multirow{3}{*}{$\mathrm{p}$-value } \\
\hline & \multicolumn{2}{|c|}{ Total } & \multicolumn{2}{|c|}{ Induced } & \multicolumn{2}{|c|}{ Spontaneous } & \\
\hline & $\mathrm{n}$ & $\%$ & $\mathrm{n}$ & $\%$ & $\mathrm{n}$ & $\%$ & \\
\hline Deciduous tooth & 237 & 76.9 & 121 & 72.0 & 116 & 82.9 & \multirow{5}{*}{0.054} \\
\hline Permanent tooth & 60 & 19.5 & 40 & 23.8 & 20 & 14.3 & \\
\hline Soft Tissue & 6 & 2.0 & 3 & 1.8 & 3 & 2.1 & \\
\hline No information & 5 & 1.6 & 4 & 2.4 & 0 & 0.0 & \\
\hline Total & 308 & 100.0 & 168 & 100.0 & 140 & 100.0 & \\
\hline
\end{tabular}

Table 3. Bivariate analysis with chi-squared test relating the type of pain reported by the assisted child and the diagnosis of the clinical conditions. Vitória-ES, 2003-2010

\begin{tabular}{|c|c|c|c|c|c|c|c|}
\hline \multirow{3}{*}{ Diagnosis } & \multicolumn{6}{|c|}{ Type of pain } & \multirow{3}{*}{$p$-value } \\
\hline & \multicolumn{2}{|c|}{ Total } & \multicolumn{2}{|c|}{ Induced } & \multicolumn{2}{|c|}{ Spontaneous } & \\
\hline & $\mathrm{n}$ & $\%$ & $\mathrm{n}$ & $\%$ & $\mathrm{n}$ & $\%$ & \\
\hline Caries Dec. w/ Pulpal Involv. & 107 & 33.5 & 28 & 26.2 & 79 & 73.8 & $<0.001^{* *}$ \\
\hline Caries Deciduous Tooth & 49 & 15.4 & 35 & 71.4 & 14 & 28.6 & $0.010^{\star \star}$ \\
\hline Caries Perm. w/ Pulpal Involv. & 23 & 7.2 & 11 & 47.8 & 12 & 52.2 & 0.501 \\
\hline Caries in Perm. Tooth & 12 & 3.8 & 10 & 83.3 & 2 & 16.7 & $0.041^{\star \star}$ \\
\hline Residual Root Dec. Tooth & 14 & 4.4 & 8 & 57.1 & 6 & 42.9 & 0.842 \\
\hline Trauma Deciduous Tooth & 44 & 13.8 & 31 & 70.5 & 13 & 29.5 & $0.022^{\star \star}$ \\
\hline Trauma Permanent Tooth & 26 & 8.2 & 20 & 76.9 & 6 & 23.1 & $0.017^{\star \star}$ \\
\hline Prolonged Ret. Dec. Tooth & 25 & 7.8 & 18 & 72.0 & 7 & 28.0 & 0.095 \\
\hline Alterations in Periodontum & 12 & 3.8 & 7 & 58.3 & 5 & 41.7 & 0.155 \\
\hline Malformation/occlusion & 3 & 0.9 & 2 & 66.7 & 1 & 33.3 & 0.672 \\
\hline Delayed Eruption of Perm. & 2 & 0.6 & 1 & 50.0 & 1 & 50.0 & 0.897 \\
\hline Total & $317^{*}$ & 100.0 & 171 & 53.9 & 146 & 46.1 & - \\
\hline
\end{tabular}

* A child may have more than one tooth with induced and/or spontaneous pain

$* * p<0.05$. 
Table 4. Bivariate analysis with chi-squared test relating the type of pain reported by the assisted child and the types of treatment performed. Vitória-ES, 2003-2010.

\begin{tabular}{|c|c|c|c|c|c|c|c|}
\hline \multirow{3}{*}{ Type of treatment } & \multicolumn{6}{|c|}{ Type of pain } & \multirow{3}{*}{ p-value } \\
\hline & \multicolumn{2}{|c|}{ Total } & \multicolumn{2}{|c|}{ Induced } & \multicolumn{2}{|c|}{ Spontaneous } & \\
\hline & $n$ & $\%$ & $\mathrm{n}$ & $\%$ & $n$ & $\%$ & \\
\hline Extraction Deciduous Tooth & 66 & 21.4 & 32 & 48.5 & 34 & 51.5 & 0.265 \\
\hline Extraction of Supernumerary & 2 & 0.6 & 1 & 50 & 1 & 50 & 0.897 \\
\hline Extraction of Residual Root & 12 & 3.9 & 8 & 66.7 & 4 & 33.3 & 0.390 \\
\hline Temporary Restoration & 33 & 10.7 & 27 & 81.8 & 6 & 18.2 & $0.001^{* *}$ \\
\hline Restoration & 24 & 7.8 & 17 & 70.8 & 7 & 29.2 & 0.095 \\
\hline Endodontic Treatment Dec. & 21 & 6.8 & 5 & 23.8 & 16 & 76.2 & $0.003^{* *}$ \\
\hline Endodontic Medication & 51 & 16.6 & 12 & 23.5 & 39 & 76.5 & $0.001^{* *}$ \\
\hline Endodontic Medic. Perm. & 7 & 2.3 & 2 & 28.6 & 5 & 71.4 & 0.163 \\
\hline Medication & 9 & 2.9 & 6 & 66.7 & 3 & 33.3 & 0.459 \\
\hline Fragment Bonding & 2 & 0.6 & 2 & 100 & 0 & 0.0 & 0.195 \\
\hline Semirigid Splint & 1 & 0.3 & 1 & 100 & 0 & 0.0 & 0.361 \\
\hline Basic Periodontal Therapy & 4 & 1.3 & 2 & 50 & 2 & 50 & 0.854 \\
\hline Soft Tissue Excision & 1 & 0.3 & 1 & 100 & 0 & 0.0 & 0.361 \\
\hline No treatment* & 75 & 24.4 & 65 & 86.7 & 10 & 23.3 & - \\
\hline Total & 308 & 100.0 & 181 & 58.8 & 127 & 41.2 & - \\
\hline
\end{tabular}

* Referred for treatment at other college clinics.

** $\mathrm{p}<0.05$.

Table 5. Bivariate analysis with chi-squared test of variables related to the type of odontogenic pain and referrals for further treatment. Vitória-ES, 2003-2010.

\begin{tabular}{|c|c|c|c|c|c|c|c|}
\hline \multirow{3}{*}{ Referral } & \multicolumn{6}{|c|}{ Type of pain } & \multirow{3}{*}{$p$-value } \\
\hline & \multicolumn{2}{|c|}{ Total } & \multicolumn{2}{|c|}{ Induced } & \multicolumn{2}{|c|}{ Spontaneous } & \\
\hline & $\mathrm{n}$ & $\%$ & $\mathrm{n}$ & $\%$ & $\mathrm{n}$ & $\%$ & \\
\hline Pediatric Dentistry & 108 & 58.7 & 58 & 53.7 & 50 & 46.3 & 0.827 \\
\hline Dental Trauma Project & 28 & 15.2 & 24 & 85.7 & 4 & 14.3 & $0.001^{*}$ \\
\hline Permanent Teeth Endodontics & 25 & 13.6 & 11 & 44.0 & 14 & 56.0 & 0.269 \\
\hline Others & 8 & 4.3 & 6 & 75.0 & 2 & 25.0 & 0.239 \\
\hline Baby Project & 6 & 3.3 & 4 & 66.7 & 2 & 33.3 & 0.547 \\
\hline Pediatric Integrated Clinic & 3 & 1.6 & 1 & 33.3 & 2 & 66.7 & 0.458 \\
\hline Pediatric Dentistry Specializ. & 3 & 1.6 & 3 & 100 & 0 & 50.0 & 0.112 \\
\hline Oral Surgery I & 3 & 1.6 & 1 & 33.3 & 2 & 66.7 & 0.458 \\
\hline Total & 184 & 100.0 & 108 & 58.7 & 76 & 41.3 & - \\
\hline
\end{tabular}

\section{DISCUSSION}

In the present study, odontogenic pain was reported by more than half of the patients who sought the emergency service. Even though there is great variation in the prevalence of dental pain in children, this divergence can be explained by differences in the methodological design of the epidemiological studies. There is a higher prevalence of dental pain in surveys performed in dental emergency services when compared to the ones performed in schools $[12,20]$ and in older children $[9,11,13,18,20]$.
As observed in this study, other surveys in emergency services find a higher prevalence of pain in children with mixed dentition, where the deciduous teeth are the most affected by pain $[9,12]$ because they have been in the oral cavity for a longer period of time and thus are exposed to a greater risk of oral diseases, especially dental caries. Another aspect that could justify this situation is a better perception of pain [3]. However, no studies performed in emergency services analyzed the association between the type of pain and age, and it was not possible to compare our results with similar studies, in which this association was not found. In a 
study involving children of 7 and 8 years of age conducted in the South of Brazil, there was a greater association between the presence of odontogenic spontaneous pain in eight yearold children when compared to seven year-old children, but no difference was found regarding induced pain [13].

There is a great divergence in the literature on the association between dental pain and gender. Lacerda et al. [13] in a multilevel study found an association between odontogenic pain and female gender. This result was also found by most studies conducted in Brazil [9, 10, 13, 21-23]. However, other studies performed in dental emergency services documented a higher prevalence in the male gender [11, 12]. Nevertheless, the results from Comunello [20] and the present study showed no difference between genders.

Even though there has been a greater investment in public health in the last decades, including oral health, and a significant decrease in dental caries among children [24], this disease is still the main reason for the demand of dental emergency services [9-13] and is associated to odontogenic pain in epidemiological studies involving children and adolescents in Brazil $[2,3,10,13,14]$. However, in other countries, such as Taiwan [25] orodental trauma was the main reason of the demand, followed by pulpal pain. These results demonstrate that dental caries are still a public health problem in Brazil, specially because of the population's lack of access to dental treatment and the lack of knowledge about the disease prevention methods [13].

Although Lacerda et al. [13] verified that children who have never been to the dentist present greater chances of suffering from odontogenic pain, some recent studies have shown that the occurrence of pain is greater among individuals who seek dental services, because of the recurrence of the need of dental treatment as a consequence of pain and worsening of oral diseases or the lack of solvability of the previously received treatment [3]. A large proportion of children seek dental care for the first time due to emergency situations, and that is one of the main reasons why parents take their children to the dentist [12]. In this regard, preventive oral health programs need to be more effective in order to develop community awareness of the importance of regular visits to the dentist and reduce the number of emergency visits [12].

The greater demand in cases of dental emergencies helps the understanding that treatment staging in the initial stages of dental caries leads to its progression, and inevitably reduces the chances of a less invasive treatment, thus making dental extraction the only viable option [26]. This mechanism may justify the extraction of deciduous teeth as the main form of treatment, as shown in the present study and in other studies found in the literature $[9,11]$. Shqair et al. [12] established that endodontic treatment was the main treatment modality. In the present study, it was also highly frequent, and decision-making depends on the professional's clinical experience and the disease stage.

The results of the present study demonstrate that induced pain is associated with the initial stages of dental caries and dental trauma in deciduous and permanent teeth, and also with the form of dental treatment, if temporary restoration and/or referral to specialized care at the dental trauma project. Spontaneous pain was associated with deciduous tooth with pulpal involvement and, its form of treatment was endodontic medication and endodontic treatment. In this regard, eliminating pain and avoiding emergency complications are an important part of the pediatric dental practice. It is important that the dentist has sufficient knowledge to make quick decisions to relieve pain and discomfort, especially in children [12].

Since all the problems are not always solved in urgent care, $184(59.7 \%)$ children who suffered from pain were referred to other clinics for treatment. Most of these children were treated by the Pediatric Dentistry clinic (58.7\%), followed by the Permanent Teeth Endodontics clinic (13.6\%). Paschoal et al. [11] found a lower number of referrals $(27.02 \%)$, and they were mainly to the following clinics from the Faculdade de Odontologia de Bauru (FOB-USP): Pediatric Dentistry (59.28\%), Endodontics (14.97\%), Restorative Dentistry (14.07\%), Orthodontics (4.19\%), Stomatology (4.19\%) and others (1.21\%).

This study has some limitations. For example, its transversal approach, making it not possible to assess causality. In addition, because it was done with clinical files, there are limitations, such as the variables that could be associated with the presence of odontogenic pain. Since this research was made in a public health service, there are biases present, such as socioeconomic status $[2,6,14$, $22,23]$, schooling [14], access to dental treatment [3,13] and impact on quality of life [1-3] that have been discussed in population-based studies as associated with the dependent variable studied. However, clinical trials have a greater power of verifying the presence of pain, since it is the main reason for the demand. Populationbased studies present difficulties in this assessment, mainly because they are based on reports from parents or caregivers and thus, may have errors. Furthermore, the subjectivity of such information is also a difficulty, since the method of measuring pain is still a challenge for health professionals $[3,14]$.

Oral-health interventional programs or policies must include strategies for health promotion, including prevention and treatment of dental caries. Increased access to dental services, as well as preventive and health education measures, can have a positive impact on the decrease of the caries index and, consequently, the occurrence of odontogenic pain. Knowledge of the prevalence of odontogenic pain and its associated factors may allow the expansion of public policies aimed at the improvement of oral health conditions and daily life $[3,14]$. The children population presents anxiety and fear concerning dental care, especially in an emergency context. The existence of preventive strategies is an incentive for parents and guardians to adopt healthy behaviors for their children, and thus the invasive treatment would not be necessary $[26,27]$. 


\section{CONCLUSION}

There was higher prevalence of odontogenic pain among children attending the dental emergency service, occurring mainly in teeth that present dental caries, in the deciduous dentition of children between 4 and 8 years of age. The type of odontogenic pain was not associated with gender and age, but it was associated with diagnosis and treatment. Spontaneous pain was associated with pulpal involvement and induced pain was associated with dental caries and dental trauma.

\section{REFERENCES}

1. Peretz $B$, Sarnat $H$. Relations between dental and somatic pain in children Int J Paediatr Dent 2010;20:201-6. https://doi.org/10.1111/j.1365263X.2010.01041.x

2. Boeira GF, Correa MB, Peres KG, Peres MA, Santos IS, Matijasevich A et al. Caries is the main cause for dental pain in childhood: findings from a birth cohort. Caries Res 2012;46:488-95. https://doi.org/10.1159/ 000339491

3. Souza JGS, Martins AMEBL. Dental pain and associated factors in Brazilian preschoolers. Rev Paul Pediatr 2016;34:336-42. https://doi. org/10.1016/j.rpped.2015.12.007

4. Gherunpong S, Tsakos G, Sheiham A. The prevalence and severity of oral impacts on daily performances in Thai primary school children. Health Qual Life Outcomes 2004;2:57. https://doi.org/10.1186/1477-7525-2-57

5. Feitosa S, Colares V, Pinkham J. The psychosocial effects of severe caries in 4-year-old children in Recife, Pernambuco, Brazil. Cad Saude Publica 2005;21:1550-6. https://doi.org/10.1590/S0102-311X2005000500028

6. Guskuma RC, Lages VA, Hafner MB, Rando-Meirelles MPM, Cypriano S, Sousa MLR, Batista MJ. Fatores associados à prevalência e intensidade de odontalgia em crianças de municípios da região de Campinas, SP. Rev Paul Pediatr 2017;35:1-9. https://doi.org/10.1590/19840462/;2017;35;3;00001

7. Edelstein B, Vargas CM, Candelaria D, Vemuri M. Experience and policy implications of children presenting with dental emergencies to US pediatric dentistry training programs. Pediatr Dent 2006;28:431-7.

8. Okeson JP. Dores odontogênicas. In: Okeson JP. Dores bucofaciais de Bell tratamento clínico da dor bucofacial. 6ª ed. São Paulo: Quintessence; 2006. p. 259-86

9. Amorim NA, Silva TRC, Santos LM, Tenório MDH, Reis JIL. Urgência em Odontopediatria. Pesq Bras Odontoped Clin Integr 2007; 7: 223-7. https:// doi.org/10.4034/1519.0501.2007.0073.0005

10. Bastos JL, Peres MA, Peres KG, Araujo CL, Menezes AM. Toothache prevalence and associated factors: a life course study from birth to age 12 yr. Eur J Oral Sci 2008;116:458-66. https://doi.org/10.1111/j.16000722.2008.00566.x

11. Paschoal MAB, Gurgel CV, Neto NL, Kobayashi TY, Moura S, Silva BR, Abdo CC, Machado MAAM. Perfil de tratamento de urgência de crianças de 0 a 12 anos de idade, atendidas no Serviço de Urgência Odontológica da Faculdade de Odontologia de Bauru da Universidade de São Paulo. Odontol Clín-Cient 2010;9:243-7.
12. Shqair AQ, Gomes GB, Oliveira A, Goettems ML, Romano AR, Schardozim LR, Bonow MLM, Torriani DD. Dental emergencies in a university pediatric dentistry clinic: a retrospective study. Braz Oral Res 2012;26:50-6. https:// doi.org/10.1590/S1806-83242012000100009

13. Lacerda J, BEM Pereira M, Traebert J. Dental pain in Brazilian schoolchildren: a cross-sectional study. Int J Paediatr Dent 2013; 23: 131-7. https://doi.org/10.1111/j.1365-263X.2012.01235.x

14. Ferreira-Junior OM, Freire MCM, Moreira RS, Costa LR. Contextual and individual determinants of dental pain in preschool children. Community Dent Oral Epidemiol 2015;43:349-56. https://doi.org/10.1111/cdoe.12159

15. Klatchoian DA. Psicologia Odontopediátrica. São Paulo: Sarvier; 1993

16. Pimenta CAM, Portnoi AG. Dor e Cultura. In: Carvalho MM. Dor: um estudo multidisciplinar. São Paulo: Summus; 1999.p.159-173.

17. Faraco JR. IM, Feldens CA. Dor em odontopediatria. In: Estrela C. Dor odontogênica. São Paulo: Artes Médicas; 2001. p.185-209.

18. Figueiredo $P B A$, Silva $A R Q$, Silva Al, Silva $B Q$. Perfil do atendimento odontopediátrico no setor de urgência e emergência da clínica odontológica do Centro Universitário do Pará - CESUPA. Arq Odontol 2013;49:88-95. https://doi.org/10.7308/aodontol/2013.49.2.06

19. Guedes-Pinto AC. Odontopediatria. 8a ed. São Paulo: Santos; 2010.

20. Comunello SMH, Crosato EM, Biazevic MGH. Dor dental e Condição Sócio-Econômica: um Estudo Censitário em Escolares. Pesq Bras Odontoped Clin Integr 2008;8:63-7. https://doi.org/10.4034/1519.0501. 2008.0081.0012

21. Peres MA, Peres KG, Frias AC, Antunes JL. Contextual and individual assessment of dental pain period prevalence in adolescents: a multilevel approach. BMC Oral Health 2010;10:20. https://doi.org/10.1186/14726831-10-20

22. Moura-Leite FR, Ramos-Jorge J, Ramos-Jorge ML, Paiva SM, Vale MP, Pordeus IA. Impact of dental pain on daily living of five-year-old Brazilian preschool children: prevalence and associated factors. Eur Arch Paediatr Dent 2011;12:293-7. https://doi.org/10.1007/BF03262826

23. Freire MCM, Leles CR, Sardinha LMV, Paludetto Junior M, Malta DC, Peres MA. Dor dentaria e fatores associados em adolescentes brasileiros: a Pesquisa Nacional de Saude do Escolar (PeNSE), Brasil, 2009. Cad Saude Publica 2012;28:133-45. https://doi.org/10.1590/S0102$311 \times 2012001300014$

24. Kassebaum NJ, Bernabé E, Dahiya M, Bhandari B, Murray CJ, Marcenes W. Global burden of untreated caries: a systematic review and metaregression. J Dent Res 2015;94:650-8. https://doi.org/10.1177/0022034515573272

25. Jung CP, Tsai Al, Chen CM. A 2-year retrospective study of pediatric dental emergency visits at a hospital emergency center in Taiwan. Biomed $J$ 2016;39:207-13. https://doi.org/10.1016/j.bj.2016.06.004

26. Silva-Junior MF, Souza, ACC, Batista MJ, Sousa MLR. Oral health condition and reasons for tooth extraction among an adult population (20-64 years). Ciênc Saúde Coletiva. 2017; 22(8):2693-702. http://dx.doi. org/10.1590/1413-81232017228.22212015

27. Moura-Leite FR, Ramos-Jorge ML, Bonanato K, Paiva SM, Vale MP Pordeus IA. Prevalence, intensity and impact of dental pain in 5-year-old preschool children. Oral Health Prev Dent 2008;6:295-30.

28. Ramos-Jorge J, Marques LS, Homem MA, Paiva SM, Ferreira MC, Ferreira FO, Ramos-Jorge ML. Degree of dental anxiety in children with and without toothache: prospective assessment. Int J Paediatr Dent 2013;23:125-30. https://doi.org/10.1111/j.1365-263X.2012.01234.x 